\title{
Building Localities without a Heimat. A Biographical Analysis of Migration and Activism in Germany
}

\author{
Victoria Taboada Gómez.
}

i will be african/ even if you want me to be german/ and i will be german/ even if my blackness/ does not suit you/ $\mathrm{i}$ will go/ yet another step further/ to the furthest edge/ where my sisters where/ my brothers stand/ where/ our/ FREEDOM/ begins/ i will go/ yet another step further and/ another step and/ will return/ when $i$ want/ if $i$ want/ and remain/ borderless and brazen

May Ayim 2008[1990]

\section{Introduction}

This article is based on the analysis of the phenomena of migration in Germany which I presented in my Master's thesis (Taboada Gómez 2018). By adopting a biographical perspective, I deconstruct the fixity of categories such as national belonging and identity, in order to be able to trace and reconstruct positioning and boundary-making processes.

Thinking in terms of the nation-state generally leads to concepts of assimilation or integration (Anthias 2009; Apitzsch 1997; Brubaker 2004; Glick Schiller 2007; Wimmer 2007). Here, a linear pathway is drawn to locate migrants as essentially

Taboada Gómez, V. (2020): Building Localities without a Heimat. A Biographical Analysis of Migration and Activism in Germany. In: Babl, E./Becker, J. (eds.): Global Processes of Flight and Migration. The Explanatory Power of Case Studies / Globale Flucht-und Migrationsprozesse. Die Erklärungskraft von Fallstudien. Göttingen: Göttingen University Press, 221-237. https:// doi.org/10.17875/gup2020-1322 
starting in a cultural "foreigner" position with the aim of ending as a cultural "native". That view is not only normative, but it departs from an inadequate conception of subjects who are seen as being in a strict relationship with nation-states, and in terms of arbitrary groupings based on ethnicity and race (Brubaker 2004).

Against this background, the construction of boundaries in migration processes is often problematized as a question of collective, ethnic or national belonging. Gabriele Rosenthal and Michaela Köttig (2009) have argued that it is necessary to reconstruct in which constellations, moments and circumstances of a migrant's life the question of belonging gains relevance, instead of assuming its importance, its effectiveness or even its existence. A more accurate picture of belonging can be gained by analyzing the context and purpose of the emergence of groupings, for example by asking when they obtain particular relevance in situations of crisis or violence.

In this article, I engage with such ideas on the basis of the biographical case reconstruction (Rosenthal 1993, 2004) of a migrant woman, Ana. ${ }^{1}$ Ana arrived in the German Democratic Republic (GDR) in the early 1960s as the child of a political refugee from Latin America. As a young adult Ana moved to West Germany, where she became increasingly active in migrants' and women's associations. I conducted a biographical narrative interview with Ana in Germany in 2017.2

In this article I analyze how the categories of "migrant" and "refugee" intertwine along a biographical trajectory. To this end, I detail how the biographical experiences related to these two categories gave Ana a sense of lack of Heimat (home). ${ }^{3}$ I show how she constructed a network and positioned herself in social relations with people for whom these categories also had a relevant role. Thus, for Ana, the lack of belonging led to the construction of localities based on activism and boundary-making processes.

I argue that the categories of "migrant" and "refugee" are not (only) the direct result of concrete experiences of mobility. Instead, they can be considered as dynamic processes of positionality in relation to other strategies used to overcome a lack of belonging, or boundary-making processes with people in similar vulnerable or marginalized situations.

\footnotetext{
${ }^{1}$ Ana is the fictional name given to the biographer. I met Ana three times for around two hours each time. The interview was conducted in Spanish. See also fn6.

2 When I started working on this topic, I was motivated by my own personal circumstances as a newcomer in Germany. I approached different migrants' organizations and interviewed migrants from Latin America. I soon realized that the migration experiences of the people I encountered during my fieldwork were very diverse and, above all, that we did not share the commonalities I hoped for concerning gender, ethnicity, nationality, and even our migrant status itself. I was assuming a natural grouping of Latin Americans based on national origins, and had a fixed idea of the notion of "migrant" as an outcome of a delimited experience of mobility and without considering historical backgrounds. In my research I analyzed my own positionality and the fixity of categories in migration research based on the debates about "insider research" (Nowicka/Ryan 2015) and methodological nationalism (Wimmer/Glick Schiller 2003; Nowicka/Cieslik 2013). Even though this is a very important aspect of doing research in the field of migration, I will not develop this topic within the framework of this article.

${ }^{3}$ In this article I do not engage with the debates on the meanings of Heimat but rather focus on the meanings the biographer assigns to it and on its effects for her biography.
} 
In the first part of the article I concentrate on Ana's life history. I show how being a refugee or migrant affects her feelings of foreignness and lack of Heimat. In the next part, based on a boundary-making perspective and the analysis of political narratives, I reconstruct how the biographer Ana found ways to appropriate her foreignness as a particular way of belonging, with the professional and personal aim of supporting others in similar situations. Finally, I conclude by showing how the categories of "refugee" and "migrant" are hard to separate within a biography and above all, that they are ongoing positionalities that are used to transform present circumstances and future perspectives through political narratives.

\section{A Politicized History of Refugees and Migration: From Latin America to East and West Germany}

Ana was born in 1955 in Latin America. ${ }^{4}$ At the age of two, her mother separated from her father and took her and her older sister to a neighboring country, trying to avoid contact between her daughters and their father. There, her mother was a member of the communist party at a time when this party suffered political persecution. As a member of the party, she was granted a scholarship to study in a socialist country. She chose to study in the German Democratic Republic, arriving there in 1963 with her two daughters as political refugees. Once in the GDR, the three of them resided in a reception center and Ana's mother had to work in a factory for one year to then be able to start her studies. The fact that Ana can only refer to this period "as a time when terrible things happened" indicates that she had a stressful and burdening time in the reception center.

During the first years in the GDR, Ana suffered racism, which included namecalling, being treated with disrespect, and receiving physical threats from other children, as well as from adult strangers on the streets and from people in school. Later in her life, Ana will dedicate herself professionally to anti-racism training in different contexts (university, consulting, civil associations) and she will also form networks with other women who position themselves as "Blacks". This seems to indicate that her childhood experiences of discrimination and racism developed into a particular awareness of, and engagement with, these topics.

At school in the GDR she stopped talking to almost everyone around her, and she refused to eat, which led to undernourishment and periods in hospital to treat it. Ana was in this way showing signs of resistance and suffering. After negotiations between her mother and school directors, teachers, and even a representative from the communist party, Ana changed school and concluded her studies.

Being a child, with no participation in the family's decision-making processes, her migration meant a radical separation from her father and her country of origin.

${ }^{4}$ I do not name the specific country or city for the sake of anonymity. While I considered the context and history of each country in the case reconstruction, here the omission of this data does not structurally affect the analysis. 
These circumstances determined, to some extent, a developing conflict in her positioning in society: her departure from "the continent", as she names it, ${ }^{5}$ when she was only a child prevented her from building a connection to a locality in Latin America, and she is therefore deprived of that constitutive biographical reference, a "place of origin":

For me, my mother's decision to take us to the DDR is a step with which until now that I am so old, I have not come to terms with myself, for me it was fatal ... I never would have wanted ... to think. That topic, I have worked a lot with it but I believe that if it had been for me, or if they had asked me, if I had been able to take a decision, I would never have left the continent, with all the problems that there are [laughs] everyone says "Oh but there, life is so hard and this and this and this", but ...6

Ana uses the word "fatal", which in Spanish is used to describe something that causes harm and that is unavoidable, even something determined by destiny, to talk about her mother's decision to move to the GDR. This could refer to very concrete experiences, such as having been left without a paternal figure, or the time she spent in a reception camp, or her exposure to racism and the overall feeling of living in a restrictive environment in the GDR. The feeling of "fatality" can be seen in her "rebellion" as a child, and also on a more interpretative level in the ongoing conflict she developed between attempts to settle down and her desire to "go back" to "the continent", even if she had no memories of a "place of origin" in Latin America as a child. The main point is not that she wants to "return" to a particular country or city: this could be anywhere in the continent. The main point is the fact of her mother deciding to cut all ties and go to the GDR, and the burdening circumstances she encountered there during the first years.

Different migration movements, and especially those starting in the 1970s, contributed to the arrival of Latin American migrants and refugees in Germany. Dreier (2000) and Hernández (2006) have shown how these movements were due to

5 The biographer herself used the term "the continent" instead of mentioning a particular country or city in Latin America. Hence, I follow this practice or use the term "Latin America".

${ }^{6}$ All quotes are translated by me. In the translation and transcription of the passages, I remain as close as possible to the spirit of the interviewee, without compromising understanding of the passages for the reader. Besides, the translator's socialization, cultural background, linguistic competence and knowledge of the culture of the people under study all play a role in the quality of the translation and are closely related to the debate on researcher positionality (Gawlewicz 2016). In practical terms, I have translated everything she said in Spanish into English, while keeping the expressions in German untranslated. I made this decision because it reflects how the interviewee spoke about particular circumstances and concepts which she could not express in her mother-tongue, Spanish. I must also say that while my mother-tongue is also Spanish, something that prompted the informal and relaxed linguistic exchange I felt while interviewing Ana, this common language doesn't necessarily imply cultural linguistic commonalities. Spanish is very diverse across countries and localities. Mostly, the interviewee kept to a "neutral" use of the language, that is to say, without culturally distinctive words. I noticed this only when transcribing the interview, and in the recording I also heard myself using "neutral" words, avoiding slang or other particular terms. This shows how both of us assumed a linguistic distance that led to the use of "neutral Spanish". At least in the selected passages, this is the dominant tendency, and it is what I observe in most of the interview. Other linguistic features, such as the use of we/they/us as commonly used by migrants when relating to migrant researchers' experiences (ibid.), were considered in the development of hypotheses during the analysis of the interview. 
political persecution during dictatorial regimes in Latin America. For instance, around 2,000 Chileans arrived in the GDR as political refugees after the coup against Allende's socialist government in 1973 (Bade/Oltmer 2004). During the 1980s another wave, mostly of Cubans and Nicaraguans, arrived in the GDR for educational, work and political purposes (Hernández 2006; Vogel/Wunderlich 2011; Kunze/Vogel 2010). Thus, during Ana's adolescence she and her family were used to socializing with Latin American migrants and refugees "from the left" who were also living in the GDR. She was surrounded by political discussions, but according to her, these were mostly sectarian, with strict points of view and with little room for criticism.

When she finished high school, her options in respect of choosing a subject to study were limited because she was not a member of the socialist party or part of the government, something she refused to do and saw with critical eyes. Her sister faced a similar situation and had to choose another subject, also because she was not a member of the party. After one year of studies that were not of her preference, Ana's sister moved to West Germany. Shortly after, Ana followed to start her university studies, and Ana's mother returned to her country of origin. To study in West Germany was possible for both of them, given that they had Latin American citizenship. Besides not being able to choose her studies in the GDR, Ana criticized the lack of freedom of speech and thought which she observed in the GDR. In respect of her impressions of the GDR and her move to West Germany, Ana explains:

Our [Ana and her sister's], let's say our position, our education, was always from the left, a lot and a lot of people from left positions from Latin America would come to our house, so it's not that we liked the ways of capitalism, it's not about us having chosen capitalism as society but that in reality, the DDR was a very closed country, it was a dictatorship, you cannot say something else! People would be scared of talking, of speaking with others, a whole lot of things.

After their first year living in West Germany, Ana and her sister visited their country of origin for the first time. They continued living in West Germany. One year before graduating, Ana had a son and married. After obtaining her degree, Ana, her husband and her son moved to Latin America with financial support from the German Government for returnees. To return to her home country was Ana's goal and main purpose, and she hoped that with a degree she could get a job and live there with her family. But once there Ana encountered difficulties both on a professional and on a personal level. Finding a job without personal contacts was extremely difficult and having a degree was not enough. Ana realized she was encountering a foreign world with dynamics that left her in a disadvantaged position. In the end, she found a job in the field of education, and even if it was poorly paid, she found it very motivating and fulfilling. While her professional life was looking up, her relationship with her mother and with her husband worsened. In addition, her son fell ill. After almost two years, and despite Ana's efforts and desire to stay, the three of them returned to West Germany. Once there, the son recovered and entered kindergarten. 
When her son entered school, Ana became engaged in various school activities, including supporting teachers' strikes and being the parents' representative. Ana was thus for the first time starting to focus on her life in Germany. By engaging in school activities and by creating "a family" for her child, Ana demonstrates that she is focusing on creating local bonds.

Ana had a second child and she separated from her husband. She started working in several social projects related to education with a group of academics. She was also offered a position as a university teacher, where she connected with academics from different countries. They formed a working group dedicated to anti-racism training. In this context, Ana formed a feminist group that positioned itself as "the Black Women". With this group, Ana carried out various projects for women. As a single mother, she managed to connect with other mothers, migrants, and activist women:

We did not suffer from the division of Germany, because we did not have relatives in the Ost nor West, we had relatives thousands of kilometers away! [laughs] Then we had already created our families, because the friends, the companions of that time are my friends, they are my sisters until now, my children have grown up with their children, until now my children and their children feel like cousins when they see each other, they greet each other as if they were cousins, we created our migrant families here, we solved our lives, I was left alone with my children, I was soon left alone with my children and I say today, when I think how did I do it? How did I manage my life? Working, activist, housewife, and children, caring for them, how did I do it? Without my friends I wouldn't have made it without my friends, they were my friends, they were what grandmothers were, aunts, sisters, everything, I had no one, absolutely no one. So, those things were, it was already our life here.

Through her projects and personal activities, Ana not only found support for herself in the task of being a working mother, but she also showed commitment to creating a long-lasting structure of support for others in a similar position. She also indicates that the division of Germany didn't play a central role in the configuration of family constellations with both transnational and local elements.

After the reunification of Germany, when Ana was 35 years old, the association lost its financial support and she faced unemployment. She went to the Job Agency looking for courses that could help her get a job. There, she encountered an employee who refused to grant her a course on the grounds that she was too "old" to learn something new. Affronted by this, Ana asked for the supervisor and finally got the courses granted.

Well I told him "you are going to search for an Angebot right away, ich möchte Betriebsorganisation [studieren] sofort! Machen Sie das sofort?" In one minute he got it for me. We were at that level here, because I was a foreigner! They had the order of qualifying only German people! That was the order! That was known through media and everything [laughs] 
it was hilarious then he gave it to me [laughs], and I said "sehen Sie?" and I told him that I know how to study and all that, "überlassen Sie mir, das ist meine Sache ja?"

Even though Ana had lived in Germany for most of her life, this anecdote shows that other people, such as the employee in the Job Agency, perceived her as a foreigner, not least because she did not have German citizenship, and that this influenced the way they treated her. At the same time, it is very clear that Ana could counter this situation (identified by herself as discrimination) and demand what she needed. However, this was not necessarily everyone's case, and other "foreigners" surely lacked the tools Ana had at that moment. The fact that in the future Ana would focus on working with migrants and migrants' associations to support them in their life in Germany shows that she was very aware of such situations, and wanted to help others to counter them, too.

After doing the course, Ana was still unemployed, so a friend of hers advised her to get German citizenship and to apply to a German public institution. She was accepted and was assigned to work in a cooperation project in Latin America, (in a country where she had never been before) in the field of violence against women, so she moved there with her children and stayed for five years. She then decided to return to Germany: her children were missing Germany and she did not want to keep them separated from their father.

After returning from Latin America, Ana worked for a project which involved visiting reception centers for refugees in Germany, mainly to check on their mental health and document the problems encountered by refugees. This further confirms the idea that she sought contexts where she could work through her own biographically significant experiences.

On two occasions following such visits, she suddenly fell deeply asleep while driving away from the centers, which almost caused her to crash the car. She also suffered severe hernias. Ana connects these events with her own time in a reception center in the GDR:

It turns out that when we came from [country in Latin America], when I was little, to Germany, we first went to a camp where we were received because we were political refugees, then we were political refugees in the DDR and the DDR did the same as they do now, they had small camps where people arrived. And that was a fatal experience, it was fatal that Aufnabmelager ... but with the years it's like I have forgotten, one throws things back, back, back whatever it takes right? To oblivion ... but of course, there were some things that seemed to remain in the subconscious.

Ana indicates that she was going through stressful situations during this project. Some of those situations consisted of dealing with people within the institutions who had a negative attitude toward refugees, which created a conflictive environment in her work. During the interview, she does not describe the time she spent living in a reception center, but the stress she refers to when addressing the topic,

\footnotetext{
7 Ana uses German when narrating anecdotes and dialogues that occurred in German, as a way of staging the scene and reproducing the power dynamics that were present at that moment.
} 
and her difficulties in remembering her own time living in such a center as a child, could be related to the fact that she suffered similar negative attitudes and rejection when she first arrived in the GDR. Only as an adult and with the support of psychotherapy can she assess the serious consequences of the time she spent in the reception center, and consider the physical and mental stress triggered during the project. A psychologist diagnosed her with re-trauma.

Throughout her life Ana developed her professional career along the lines of working with academics from different countries, as well as with other migrants and feminist women. She continued her work with migrants, migrant associations, and anti-racism training by forming and assessing associations dedicated to that topic. Thus, Ana reinforced her social positioning as a migrant and her eagerness to contribute to migrants' visibility by considering her own experience and its potential to help others: 'I mean we are like a testimony that we live, migrants' associations are a testimony that migrants exist ok? The ones that exist in the shadows, in reality, they stay in the shadows."

The fact that Ana had gone through experiences of exclusion, and difficulty in feeling like a local and part of society, worked as a motivation for her political engagement in building structures for other migrants who faced similar challenges. In other words, Ana's knowledge and transnational experiences can be seen not only as traumatic suffering, but also, and even more importantly, as resources that can be used to help others, including their children (Kontos/Ruokonen-Engler/Siouti 2014).

In the 1970s, migrant women from Latin America organized themselves in groups according to their country of origin and political orientation, to defend their rights, and to preserve and promote their culture. Stella Dreier (2000) argues that these groups always had the goal of going back to their countries of origin, which prevented them from paying attention to their role in Germany. The situation of these migrants' organizations started shifting in the early 1980s, when their focus changed to the experiences of these Latin American women as migrants, regardless of their specific country of origin or the motive for their migration. Then, in the early 1990s, women saw the necessity of organizing themselves in a more specific way: the motivations and reasons for migration were not (mainly) political anymore, but personal, professional, and even economic. They founded different associations, chiefly with the aim of supporting their entry into the job market and fostering social and cultural encounters (Dreier 2000: 23). Still, my own research with regard to current organizations shows that the history of political migrants and refugees of the 1970s is still very present in a number of associations and migrant groups. 


\section{Narrations on Lacking and Building a Heimat}

Ana's migration trajectory is constituted first by the difficult circumstances of her departure from Latin America as a child, the rupture in her primary family, and its consequences. It is also formed by her childhood in the GDR as a political refugee. The sudden change and the hostile environment she encountered, along with the rupture with her place of origin, evolved into a feeling of being displaced and a troubled relationship with her origins. This sense of strangeness between her positioning as a Latin American migrant and political refugee and the reality of having grown up in Germany contributed to making her biographical trajectory difficult and burdening.

Even if she is very much aware of this tension, she still constructs her place of birth as the place where she feels at ease, with which she preserves strong emotional bonds, and where she frequently visits family and friends. At the same time, she recognizes the implications of her abrupt departure and a lack of identification in Germany. The tension she experiences with the topic, along with her traumatic experiences in the GDR, contribute to the sensation of foreignness she has endured throughout her life, a foreignness she expresses in the present of the interview as a lack of Heimat.

At the same time, the reconstruction of her life history reveals how she developed action plans and strategies to overcome situations that were out of her control. In particular, her biography shows how specific turning points, such as her commitment toward her children, and further political activism, have helped her to make sense of her positionality as a migrant with a personal history as a political refugee.

Ana undertook concrete actions such as raising her children in Germany (avoiding long-term migration), engaging in school and other activities, and building a care circle and a family in order to assure the strengthening of local bonds for her children. This way, Ana took very different steps from the ones her mother took, creating a sense of what she defines as Heimat for her children, in contrast to what she feels as lacking for herself:

For me, I didn't have a Heimat. Until now I don't have - I feel that I have been left without a Heimat, right? So, but I thought and said, no, to my children, I will give them a home, a place where they say - in ten years they will say here I grew up, this is my home, these are my memories, like a real local bond. That was my commitment.

Throughout her narrative, Ana gives space to argumentative passages where she reflects on her situation. By explaining the strategies she engaged in to avoid the same trajectory for her children, she shows her biographical work which involves using her position as a migrant to claim her rights to a locality, her own space and her own voice. This commitment was not restricted to her children: with her civic engagement and awareness, she expanded her commitment through her professional life, with the aim of shedding light on the exclusion suffered by migrants, as well as other groups in similar situations of discrimination. 
In the following section I discuss Ana's strategies for working with her own experiences from a boundary-making perspective, centered in her case on political activism. Ana used the lack of a fixed cultural and national reference to navigate among other social divisions and power structures that she saw as shaping society and her own biography.

\section{Leaving the Periphery through Political Narratives}

\subsection{Building a Locality through Boundary-Making}

Processes of belonging may be influenced by conditions of migration, generational legacy, family history, social and political contexts, legal status, and so on. In other words, belonging is a process where collective, changing conceptions of identity interrelate with individual history in negotiating the transformation or perseverance of we-groups as social facts (Rosenthal/Köttig 2009). Thus, "the close coupling with current socio-political processes and interests makes ethnicity undoubtedly available for literally any possible purpose, particularly in situations of intensified crisis and deep insecurity" (Kössler/Schiel 1995: 10, cited in Rosenthal/Köttig 2009).

Through her civic and political engagement, Ana was able to build a supporting network. When undertaking her own projects in the field of civic activism and antiracism as a freelancer, an academic and an activist, her social relations were based on categories that were also relevant for her colleagues, as well as for the aims they were pursuing in their projects.

The process of boundary-making (Wimmer 2007) resulting from her sense of being a "foreign" woman with a critical view of reality, and a history of migration as a refugee and of having suffered racism under an authoritarian regime, were the biographical resources for this positionality. She bonded with people with whom she shared a particular political and social standpoint, as well as feelings of "foreignness" and of being racialized. This position is not dependent on a specific country of origin, but is constructed from a shared experience of exclusion, and in a context of undertaking concrete action. Ana describes her experiences of encounter and work as follows:

I entered that field, and I ran into a group of academics, all of them foreigners, all people like me.

So we decided, well, we really analyzed this intercultural communication, and we started to analyze it, and we realized that actually what was needed was an anti-racist training, so here what must be done is to work on racism, not talk about cultures, of intercultural communication, that's not it, that's not it, but rather what must be done is to work on racism. 
Processes relating to positionality and awareness were therefore achieved and developed in the framework of these encounters where people shared common goals and concerns, as well as similar histories and future perspectives.

It has been said that biographical experiences, such as episodes of discrimination during childhood, along with socialization in politically active contexts, and familial traditions of activism, can become a "source of motivation to change social circumstances through political activism" (Kontos/Ruokonen-Engler/Siouti 2014: 14). Being identified as a minority in the country of origin or migrating for political reasons are also common factors among migrants who engage in political activism, while they develop multiple memberships in more than one participation field, including migrants' organizations (ibid.).

In next section I discuss the contribution of personal trajectories such as Ana's to a wider social and academic movement, particularly when belongings and boundary-making processes turn into political processes.

\subsection{From Individual Biographies Towards Collective Action: Black Women}

When facing political, economic, or even social, moments of crisis, such as unemployment, solitude or discrimination, Ana and her group strengthened boundaries and constructed a collective positionality to face those challenges. They built on a political narrative to bind all their particularities together, with a common ideology and a very particular awareness: their condition as women and as socially marginalized people.

Groups with a history of marginalization can use their ethnicity to explain their history and to re-position themselves and their demands (Hall 1996). They must be able to negotiate their position through biographical work, challenging dominant social ascriptions (Apitzsch 2009). Biographical work, especially in migration processes, means turning conflicts and ascriptions into achievements (Apitzsch/Siouti 2007; Apitzsch 2009), for example through social participation and collective positioning.

The women in Ana's networks and communities perceived themselves as similar in ways that did not rely on ethnic or national categories. What bound them together was common questions and concerns, their personal histories, their ideas about gender and race, and about the political contributions they wanted to make. This is made clear by Ana when describing her colleagues and friends, and the activities they engaged in. Here, Ana does not avoid mentioning the conflicts and frustrations that also existed within the projects and the associations. Nevertheless, in her presentation she mainly describes the boundary-making process, stressing the organizing and connecting forces in the face of the challenges they had to overcome. The situational aspect also played a role in the dynamics of these groupings, namely the position in which Ana and her acquaintances found themselves in relation to others, and the common strategies they elaborated to counter their disadvantages. To foster their 
ideas and initiatives, they strove for institutional formality, besides cultivating their informal social and political networks.

Scholars have argued that political narratives can render power dynamics visible and can transform individual experiences into public, collective memory (Andrews 2017). In other words, "political narratives help to establish the framework through which communities make sense of themselves, and their dynamic nature is such that the past is never really past, but is rather a site of ongoing battle" (Andrews 2014: 358). Ana's political narrative is visible in her self-presentation when talking about her decision to move to West Germany as a young adult, when describing her activism and discussions with her colleagues, and finally when connecting these with her personal life: her childhood memories, her aspirations for her children, and so on.

Here, political narratives refer to stories people tell about how they see the world working, as well as to broader macro stories where individuals reflect upon their positioning and their role (Andrews 2007). They also refer to the relationship between individuals and communities, and how individuals see power relations being constructed, along with their location within these dynamics; often the narration is not explicitly about politics, but reveals the individual's political positioning (Andrews 2007, 2014). Ana's political narrative comes not only from her biographical political socialization, but is also constructed through the narrative of the group she was part of:

We created a feminist, multicultural space, so we were like 30,40 women, eh ... we were Jewish, Afro-Deutsche, Afro-Germans, migrants, refugees, women would position themselves as migrant women from Iran, etc., so, we united and created like a union of Black Women, named like that, and we requested - so we decided to create a space, a center for feminist, multicultural training, that's how we called it.

Women like Ana and her colleagues were part of an academic and civic movement that took into account the intersectional positionality of migrant women in both the academic and political agendas. By choosing the name of "Black Women", 8 they made a stand on the radical necessity of approaching the topic of migration and feminist studies from an intersectional perspective. By reflecting on their biographies, the particularities of their life as migrants, as racialized and cultural others, as mothers and as women, they could build a critical position to counter their situation of exclusion.

\footnotetext{
${ }^{8}$ Here I consider intersectionality (Crenshaw 1989, 1994) not only as an outcome in the form of a heuristic device in the present, but also within its historical emergence, which is visible in Ana's biography. At that time, it was necessary "to make perceptible migrants' gender, their gendered obligations, care responsibilities, loyalties, family ties and the like. This may include submission to dominant gender orders as well as their modification and transformation" (Lutz 2010: 1659). What is more, "immigrant and minority scholars identified politically as 'blacks', a collective identity formation which can be termed the 'radical resistance"', who reacted against the marginal place they occupied, as well as against processes of "otherness" (ibid.: 1650). Further analysis of this twofold aspect of intersectionality is beyond the scope of this article.
} 


\section{Conclusion: Belonging as a Migrant}

In this article I have attempted to reconstruct processes of positionality and boundary-making in the context of refugees and migration. In the first part, I focused on the level of action and analyzed the relevance of the categories of "refugee" and "migrant" according to the lived experiences of the biographer. Ana's biography shows that both her departure from her country of origin and her arrival in the GDR were dominated by conflicts related to her family and to circumstances that made her feel threatened, such as the time she spent in the reception center and the racism she suffered as a child. During her adolescence Ana was surrounded by political discussions which, together with the lack of freedom she experienced in the GDR, led her to decide to move to West Germany. After attempting to build a life in Latin America without success, Ana focused on her role in Germany. How could she reconcile her mother's "fatal" decision to leave her country of origin, her troubled history in East Germany, and still build a home, a Heimat, if not for herself, at least for her children?

This inner conflict led to the development of concrete strategies and actions in Ana's biography. Despite her history as a refugee and a migrant, which she first presented as a lack of belonging, Ana created a network of social relations where the categories of "refugee" and "migrant" were recognized as valid positions by other women with whom she could start a boundary-making process. This process was broadened by including the categories of motherhood and experiences of racialization. Her political activism and her work with migrants' associations are clear examples of these strategies.

On the narrated level, hegemonic discourses regarding belonging (and the need of a Heimat) are visible because the narrative refers to personal experiences of struggling to be acknowledged outside fixed national belongings or individual trajectories. This can be seen in her efforts to legitimize her transnational reality, as well as her history of refugee and migration processes that are not limited to childhood or adulthood, but have ongoing effects and also involve her family and other relationships. Ana narrates her biography with an ambiguous articulation of her aspirations to belonging and her trajectory as refugee and migrant. She is always in an in-between or Third Space (Bhabha 2004; Lutz 2011) of negotiation: the liminality (Bhabha 2004) of Ana's position served to counter the conflict created by her abrupt departure from Latin America and the locality she has built for her children and for other migrants in Germany.

Hence, Ana narrates the story of her migration back and forth to Latin America, her life in the GDR, in West Germany, and unified Germany, as processes that allowed her to build locality through boundaries based on experiences of foreignness. From this perspective, "being a refugee" interacts with other aspects of self, such as race or gender categories, and "being a migrant" is an outcome of mobility and boundary-making with other migrants. In all cases, Ana's biographical work enabled 
these categories to emerge in interplay with the context that required them to do so with more visibility.

Indeed, biographies reflect the way in which individuals organize their multiple locations and functions in modern society, where social status or identities are far from being limited to a single, stable and defined life cycle, or to static locations sustained through time (Fischer-Rosenthal 2000). Thus, "the individual as a dynamic system of plural sub-selves is realised in his or her life stories and not through a "coerced identity"' (ibid.: 116). Narrating biographies or doing biographical work is a process of self-reflexivity that renders events understandable and coherent for the individuals concerned and for others - society and institutions. To tie together a personal story that explains how the individual came to be is a reconstruction that relates an assessment of past events to future aspirations in the light of present aims (ibid.).

Ana's trajectories allowed her to build locality within her lack of Heimat. This void originated from a lack of compliance with normalized national categories in her biography, and she embraced it through political narratives that were able to legitimize that liminal space. In Ana's case, this became her professional path, based on her engagement with migrants' and refugees' associations and their struggle for visibility.

\section{References}

Andrews, M. (2007): Exploring Cross-Cultural Boundaries. In: Clandinin, D. J. (ed.): Handbook of Narrative Inquiry. Mapping a Methodology. Thousand Oaks, CA: Sage, 489-511.

Andrews, M. (2014): Narrating Moments of Political Change. In: Nesbitt-Larking, P./Kinnvall, C./Capelos, T. (eds.): The Palgrave Handbook of Global Political Psychology. London: Palgrave Macmillan, 353-368.

Andrews, M. (2017): Introduction. Political Narratives and the Study of Lives. In: Goodson, I./Antikainen, A./Sikes, P./Andrews, M. (eds.): The Routledge International Handbook on Narrative and Life History. Abingdon: Routledge, 273-279.

Anthias, F. (2009): Translocational Belonging, Identity and Generation. Questions and Problems in Migration and Ethnic Studies. In: Finnish Journal of Ethnicity and Migration, 4(1), 6-15.

Apitzsch, U. (1997): The Changing Role of Women in the Migration Process. 27th Annual SCUTREA Conference Proceedings. Crossing Borders, Breaking Boundaries. Research in the Education of Adults. Online: http://www.leeds.ac.uk/educol/documents/000000197.htm <02.07.2020>. 
Apitzsch, U. (2009): Ethnicity as Participation and Belonging. In: Rosenthal, G./Bogner, A. (eds.): Ethnicity, Belonging and Biography. Ethnographical and Biographical Perspectives. Berlin: Lit-Verlag, 83-96.

Apitzsch, U./Siouti, I. (2007): Biographical Analysis as an Interdisciplinary

Research Perspective in the Field of Migration Studies. Frankfurt a. M.: University of Frankfurt.

Ayim, M. (2008[1990]): Borderless and Brazen. A Poem against the German 'UNot-Y' Affilia. In: Journal of Women and Social Work, 23(1), 92-94.

Bade, K. J./Oltmer, J. (2004): Normalfall Migration. Bonn: Bundeszentrale für Politische Bildung, 90-96.

Bhabha, H. K. (2004): The Location of Culture. London/New York: Routledge.

Brubaker, R. (2004): Ethnicity without Groups. Cambridge, MA: Harvard University Press.

Crenshaw, K. (1989). Demarginalizing the Intersection of Race and Sex. A Black Feminist Critique of Antidiscrimination Doctrine, Feminist Theory and Antiracist Politics. In: University of Chicago Legal Forum, 140, 139-167.

Crenshaw, K. (1994): Mapping the Margins. Intersectionality, Identity Politics, and Violence against Women of Color. In: Albertson Fineman, M./Mykitiuk, R. (eds.): The Public Nature of Private Violence. New York: Routledge, 93-118.

Dreier, S. (2000): Las mujeres latinoamericanas en Alemania. Su situación de vida. In: Hernández, B. (ed.): Las mujeres inmigrantes Latinoamericanas en Alemania. Präsenz und Unsichtbarkeit. Berlin: Bildungswerk Berlin der Heinrich-Böll-Stiftung, 17-23.

Fischer-Rosenthal, W. (2000): Biographical Work and Biographical Structuring in Present Day Societies. In: Chamberlayne, P./Bornat, J./Wengraf, T. (eds.): The Turn to Biographical Methods Social Science. London/New York: Routledge, 109-125.

Gawlewicz, A. (2016): Language and Translation Strategies in Researching Migrant Experience of Difference from the Position of Migrant Researcher. In: Qualitative Research, 26(1), 27-42.

Glick Schiller, N. (2007): Beyond the Nation State and its Units of Analysis.

Towards a New Agenda for Migration Research. In: Schittenhelm, K. (ed.):

Concepts and Methods in Migration Research. Conference Reader, 39-72.

Online: http://sowi-serv2.sowi.uni-due.de/cultural-capital/reader/Conceptsand-Methods.pdf <01.06.2020>. 
Hall, S. (1996): New Ethnicities. In: Morley, D./Chen, K.-H. (eds.): Stuart Hall. Critical Dialogues in Cultural Studies. London/New York: Routledge, 442 451.

Hernández, B. (2006): Nuevas rutas, nuevas actoras. Mujeres migrantes Latinoamericanas en Alemania. In: García Gossio, M. I. (ed.): Los nuevos escenarios de la migración. Causas, condiciones, consecuencias. México: Fundación Heinrich Böll, 35-48.

Kontos, M./Ruokonen-Engler, M. K./Siouti, I. (2014): Qualitative Research to Identify Barriers of Participation. The Case of Germany. Frankfurt a. M.: Institute of Social Research at Johann Wolfgang Goethe University. Online: https:// ec.europa.eu/migrant-integration/librarydoc/qualitative-research-toidentify-barriers-of-participation-the-case-of-germany $<31.08 .2020>$.

Kunze, T./Vogel, T. (2010): Ostalgie International. Berlin: Christoph Links.

Lutz, H. (2010): Gender in the Migratory Process. In: Journal of Ethnic and Migration Studies, 36(10), 1647-1663.

Lutz, H. (2011): Lost in Translation? The Role of Language in Migrants' Biographies. What Can Micro-Sociologists Learn From Eva Hoffman? In: European Journal of Women's Studies, 18(4), 347-360.

Nowicka, M./Cieslik, A. (2013): Beyond Methodological Nationalism in Insider Research with Migrants. In: Migration Studies, 2(1), 1-15.

Nowicka, M./Ryan, L. (2015): Beyond Insiders and Outsiders in Migration Research. Rejecting A Priori Commonalities. Introduction to the FQS Thematic Section on "Researcher, Migrant, Woman: Methodological Implications of Multiple Positionalities in Migration Studies". In: Forum: Qualitative Social Research, 16(2), Art. 18. Online: http://www.qualitativeresearch.net/index.php/fqs/article/view/2342<15.07.2020>.

Rosenthal, G. (1993): Reconstruction of Life Stories. Principles of Selection in Generating Stories for Narrative Biographical Interviews. In: The Narrative Study of Lives, 1(1), 59-91.

Rosenthal, G. (2004): Biographical Research. In: Seale, C./Gobo, G./Gubrium, J. F./Silverman, D. (eds.): Qualitative Research Practice. London: Sage, 48-64.

Rosenthal, G. in collaboration with Köttig, M. (2009): Migration and Questions of Belonging. Migrants in Germany and Florida. In: Forum: Qualitative Social Research, 10(3), Art. 19. Online: http://www.qualitativeresearch.net/index.php/fqs/article/view/1372/2864<15.07.2020>.

Taboada Gómez, Victoria (2018): Trajectories of a Migrant Woman in Germany. Gaining Spaces and Voices. A Biographical Analysis. Unpublished Master's thesis, Humboldt Universität zu Berlin. 
Vogel, W. D./Wunderlich, V. (2011): Abenteuer DDR. Kubanerinnen und Kubaner im deutschen Sozialismus. Berlin: Dietz.

Wimmer, A./Glick Schiller, N. (2003): Methodological Nationalism, the Social Sciences, and the Study of Migration. An Essay in Historical Epistemology. In: International Migration Review, 37(3), 576-610.

Wimmer, A. (2007): How (Not) to Think About Ethnicity in Immigrant Societies. Toward a Boundary-Making Perspective. In: Schittenhelm, K. (ed.): Concepts and Methods in Migration Research. Conference Reader, 7-38. Online: http://sowi-serv2.sowi.uni-due.de/cultural-capital/reader/Concepts-andMethods.pdf $<01.06 .2020>$. 